\title{
Non-paradoxical Multi-location
}

DOI:

10.1093/analys/63.4.311

\section{Document Version}

Accepted author manuscript

Link to publication record in Manchester Research Explorer

\section{Citation for published version (APA):}

Beebee, H., \& Rush, M. (2003). Non-paradoxical Multi-location. Analysis, 63, 311-317.

https://doi.org/10.1093/analys/63.4.311

\section{Published in:}

Analysis

\section{Citing this paper}

Please note that where the full-text provided on Manchester Research Explorer is the Author Accepted Manuscript or Proof version this may differ from the final Published version. If citing, it is advised that you check and use the publisher's definitive version.

\section{General rights}

Copyright and moral rights for the publications made accessible in the Research Explorer are retained by the authors and/or other copyright owners and it is a condition of accessing publications that users recognise and abide by the legal requirements associated with these rights.

\section{Takedown policy}

If you believe that this document breaches copyright please refer to the University of Manchester's Takedown Procedures [http://man.ac.uk/04Y6Bo] or contact uml.scholarlycommunications@manchester.ac.uk providing relevant details, so we can investigate your claim.

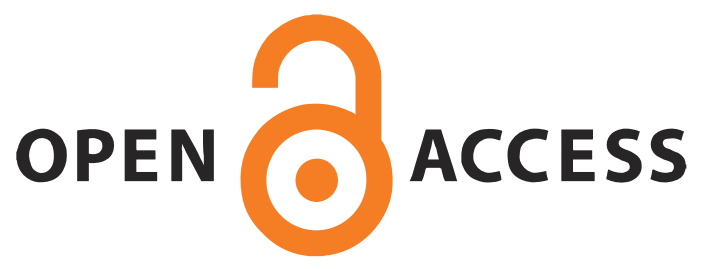




\section{Non-paradoxical multi-location}

HeLEN BeEbeE \& Michael Rush

Please do not cite this version. The published version is: 'Non-paradoxical Multilocation', with Michael Rush, Analysis 63 (2003), 311-17

\section{Introduction}

Stephen Barker and Phil Dowe (2003) claim that three paradoxes can be generated by the claim that there are multiply located entities - for example enduring particulars, enduring tropes, and immanent universals - with the second and third paradox each involving weaker assumptions than their predecessors.

We argue that neither of the first two alleged paradoxes are really paradoxes, at least with respect to the view that there are enduring particulars. It is an interesting question whether our responses can be made to work for the other cases of multiple location, but not one that we shall attempt to answer. In addition we leave to the reader the solution to the third paradox, since it turns on the same claim about temporary parts as does the solution to the second.

\section{Paradox 1}

Endurantism with respect to object $O$ is the doctrine that $O$ is wholly located at every moment at which it exists. Paradox 1 takes two alternative forms, depending on whether the endurantist wants to hold that there can be objects of zero temporal extent or, instead, that there is some quantum of time, of duration $n$, so that $n$ is the shortest period of time in which an object can exist. We take the two versions in reverse order.

Let Eric the (Short-Lived) Cat be an enduring object which exists for precisely $100 n$, between the times $t_{0}$ and $t_{100}$. Now take the 100 temporal slices of this time interval: let $r_{1}$ be the time interval between $t_{0}$ and $t_{1}, r_{2}$ be the interval between $t_{1}$ and $t_{2}$, and so on up to $r_{100}$. Existing for the duration of each slice $r$ is an entity (a cat, one might assume - but we'll come back to that). Call these objects the Eric $r$ s. Now take the fusion, or mereological sum, of all the $\mathrm{Eric}_{r} \mathrm{~s}$ and call this fusion $F\left(\mathrm{Eric}_{r}\right)$.

Paradox 1 (version 2) goes like this. (a) By hypothesis, Eric is wholly located at every moment at which he exists. So the relation between the $\mathrm{Eric}_{r} \mathrm{~s}$ is that of identity: each Eric $r$ is simply Eric. Hence the fusion of the Eric $r$ s, $F\left(\right.$ Eric $\left._{r}\right)$, is simply 
identical with each of the Eric $r$; but, since each Eric $r$ has temporal extent $n$, it follows that $F\left(\right.$ Eric $\left._{r}\right)$ also has temporal extent $n$. But (b) $F\left(\right.$ Eric $\left._{r}\right)$ has a part at each $r$. So $F\left(\right.$ Eric $\left._{r}\right)$ is an object with temporal extent $100 n$. So $F\left(\right.$ Eric $\left._{r}\right)$ 's temporal extent both is and is not greater than $n$. Paradox.

Version 1 of the paradox, the version on which we assume that objects can have zero temporal extent, slices Eric into segments $\left(\right.$ Eric $\left._{r} s\right)$ of zero temporal extent. (a) Since all the $\operatorname{Eric}_{r} \mathrm{~s}$ are identical, and each has zero temporal extent, $F\left(\right.$ Eric $\left._{r}\right)$ has zero temporal extent and hence is a $3 \mathrm{D}$ object. But (b) $F\left(\right.$ Eric $\left._{r}\right)$ has a part at each $r$, so is a $4 \mathrm{D}$ object. Paradox.

We claim that Paradox 1 equivocates with respect to the Eric $_{r} \mathrm{~s}$. According to one conception of the $\operatorname{Eric}_{r} \mathrm{~S}$ - the conception according to which they are identical with each other, as is assumed in part (a) of the argument - it is not true (contrary to what Barker and Dowe say) that any of the $\operatorname{Eric}_{r}$ s have temporal extent $n$ (or zero). According to the other conception of the $\operatorname{Eric}_{r} \mathrm{~s}$ - the conception used in part (b) each Eric ${ }_{r}$ does have temporal extent $n$ (or zero). But the fusion of the Eric $r$ s is not Eric. So the endurantist does not face a paradox; nor is she forced to admit that Eric has temporal parts.

Here is Eric at $r_{l}$, being born. Here is Eric again at $r_{50}$, playing with a ball of string. And here is Eric again, at $r_{100}$, passing away prematurely but peacefully in his sleep. Whenever I point and say, 'Look! There's Eric!' I am (according to the endurantist) pointing to the whole of Eric - that enduring entity - and not to any temporal part of him (for he has no such parts). Eric (thus conceived) does not have temporal extent $n$. After all, he lives to the ripe old age of 100n! By hypothesis, when I point to Eric at a given time, I refer to the whole enduring cat, and not to some Ericlike object that only exists for duration $n$. No such object can be Eric. Eric does not get to have temporal extent $n$ simply in virtue of existing for one instant at a time; there is just no other way of existing in time. If Eric were supposed to have temporal extent $n$ on account of existing one moment at a time, then it would be impossible for any entity to have a 'temporal extent' that was anything other than $n$. No one, we think, would see as conclusive evidence against endurance the fact that we have to take things one moment at a time. Hence there is no $F\left(\right.$ Eric $\left._{r}\right)$ that has $n$ temporal extent. The 'fusion' of all the objects I pointed to (supposing I pointed to Eric at $r_{l}$, again at $r_{2}$, and so on to $r_{100}$ ) is just the fusion of, well, Eric with himself. That fusion 
is just Eric, and he does not have temporal extent $n$. Part (a) of the argument for Paradox 1 (version 2) has a false premiss and a false conclusion.

(In fact, the endurantist might well refuse to talk in terms of 'temporal extent' at all, since, according to her, objects endure rather than extend through time. Still, we can get along with 'temporal extent' talk so long as we take ' $x$ has temporal extent $n$ ' to commit us to no more than the claim that $x$ lasts for $n$ amount of time, where 'lasts for' is neutral between 'endures through' and 'extends for'.)

Version 1 of the paradox might seem trickier. Doesn't the relevant kind of endurantist say that Eric is a 3D object, just as part (a) of the argument - the part whose (version 2) conclusion we are objecting to - says? Yes. But the intermediate conclusion of part (a) of version 1 is that $F\left(\mathrm{Eric}_{r}\right)$ is an object with zero temporal extent, and hence that $F\left(\right.$ Eric $\left._{r}\right)$ is $3 \mathrm{D}$. No sensible endurantist is going to equate being a 3D object and having zero temporal extent. For the (relevant kind of) endurantist, none of the $\operatorname{Eric}_{r}$ s have zero temporal extent, since they are all Eric, and his 'temporal extent' (in the neutral sense defined above) is $100 n$. Hence $F\left(\right.$ Eric $\left._{r}\right)$ is, again, the fusion of Eric with himself, and it - that is, Eric - has 'temporal extent' $100 n$. Eric is a $3 \mathrm{D}$ object, but not the object the first part of version 1 claims to exist. ${ }^{1}$

We are not out of the woods yet, however, because we still have the fusion of all the $\mathrm{Eric}_{r} \mathrm{~s}$, where the $\mathrm{Eric}_{r} \mathrm{~s}$ are taken to be distinct objects with $n$ (or zero) temporal extent. If that fusion turns out to be Eric, the endurantist is in trouble, because it will turn out that Eric does after all have temporal parts - all the $\mathrm{Eric}_{r} \mathrm{~s}-$ and that is precisely what the endurantist denies. (Or - to put it in terms of version 1 of the paradox - Eric will turn out to be both 3D and 4D, which is a contradiction.)

So what is this fusion? It lasts for the same amount of time as Eric - 100nand it does seem rather cat-like. But it is not (we claim on behalf of the endurantist) Eric. It is Eric's life. Eric's short life has many stages. (100 minimal ones, to be precise.) Here, at $r_{0}$, is Eric's birth. Some time around $r_{50}$, Eric enters the playingwith-balls-of-string stage. And here, at $r_{100}$, is Eric's untimely but peaceful demise. These stages - the Eric $_{r}$ s with shorter-than-100n temporal extent - are not stages of Eric, but stages of his life. When I point in Eric's direction and thereby mean to pick

\footnotetext{
${ }^{1}$ In fact, the endurantist will presumably say that Eric is a 3D object whatever they think about whether there is such a thing as zero temporal extent. Suppose we agree that $n$ is the smallest unit of time. Does that stop Eric from being 3D? Not at all. The endurantist is hardly going to say that Eric is now a 4D object with $n$ temporal extent. After all, he patently doesn't have $n$ temporal extent.
} 
out an object with temporal extent less than $100 n$, I am not picking out Eric or a temporal part of him, but rather a stage of his life. The fusion of those stages is thus not Eric but his life.

There is therefore no paradox here. We have one temporal-partless cat, and his temporal-parted life. There is a fusion of temporal parts - Eric's life - and that fusion has $100 n$ temporal extent. But there is no fusion of $n$ temporal extent and so no paradox. (Version 1: there's the 4D fusion of temporal parts - Eric's life again - and then there's 3D Eric. Different properties but different objects, so no paradox.)

One might object that the distinction between Eric and his life seems rather ad hoc. We think not. The distinction has been made and defended elsewhere, for instance by Rowland Stout, most fully in his 2003. Moreover, Barker and Dowe themselves go on to draw a distinction between an object and the life of that object in order to generate Paradox 2, to which we now turn.

\section{Paradox 2}

'Lives,' say Barker and Dowe, 'are part of common sense ontology; we speak of entities - be they people, animate entities or inanimate - having long, interesting, varied, good, etc. lives. Lives are 4D things; they have beginnings, middles, and ends. $L(O)$ [the life of object $O$ ] is just like an event occurring at a region $R$; it is located at $R$ with proper parts located at each sub-region $r$ in $R$.' (110) Quite so.

They go on to claim that, '[w]here there is a persisting thing ... there is a life, $L(O)$. There is a necessary connection between a persisting thing and its life' (ibid.). But (they say) we should accept the Humean principle, no necessary connections between distinct existences. So $O$ and $L(O)$ cannot be distinct. So (they say) we should accept that $O$ is part of $L(O)$.

Let's accept Barker and Dowe's assumption that $O$ is part of $L(O) .{ }^{2}$ Now here's Paradox 2. $L(O)$ can be split into two non-overlapping temporal stages - call them $L(O) 1$ and $L(O) 2 . L(O) 1$ is located at $R 1$ (and nowhere else), and $L(O) 2$ is located at $R 2$ (and nowhere else). By hypothesis, $O$ is part of $L(O)$. So (allegedly) $O$ is part of $L(O) 1$. But $O$ is located at $r$ s that are not in $R 1$, so $L(O) 1$ cannot, contrary to

\footnotetext{
${ }^{2}$ Actually, we doubt whether an endurantist will accept that assumption since, for the endurantist, objects and their lives inhabit very different ontological categories. It is very hard to see how something that endures through time could be part of something that extends through time.
} 
hypothesis, be confined to $R 1$ ( since $O$ is part of $L(O) 1$ ). Similarly for $L(O) 2$. Paradox.

What's gone wrong here? First it will be useful to consider what an endurantist might say about the problem of temporary intrinsics. It is a welldocumented response to the supposed problem of how one and the same entity can endure through changes in its intrinsic properties (losing property $F$, say) to say that there is no paradox because such an entity has-at- $t_{1}$ property $F$, and does not have-at$t_{2}$ property $F$. In other words we relativize the instantiation relation, a course of action often referred to as the 'adverbial' solution. Sally Haslanger, a defender of this approach, says that the 'intuitive idea behind the so-called 'adverbial' option is that objects have properties at times, and that time should modify this 'having' rather than the subject or the property' (1989: 120).

This solution is often overlooked. Mark Johnston (1987) says that 'the problem of identity through intrinsic change looked like a problem only because we forgot about the possibility of relativizing the instantiation relation' (1987: 129). Enduring entities have their properties not timelessly but at-a-time. How can one and the same enduring cat be playful and asleep? Simple: it is has-at- $t_{43}$ the property of being playful and has-at- $t_{78}$ the property of being asleep. Eric enjoys tensed attributions of properties. Properties of Eric's life, on the other hand, are had timelessly by his life. For instance Eric's birth has timelessly the property of taking place at $t_{0}$.

Now, what goes for instantiation goes, we claim, equally for parthood. One of us was once (an ineffectual) part of his cub-scout football team. Let's suppose for the sake of the argument that the team folded (rather than rejoiced) as soon as he quit. The relation between Michael and the team was, but no longer is, a part-whole relation: he was, but no longer is, a part of that team. The team was, but no longer is, partly located wherever Michael was located. In other words, Michael was a temporary part of the team. All this, we suggest, is just plain common sense for the endurantist.

The relationship between $O, L(O) 1$ and $L(O) 2$ is similar (supposing that the relation is genuinely part-whole). Let's use Eric again, and divide his life into his Youth and his Twilight Years. Eric was once (quite literally on current assumptions) in his Youth - he was, once, a part of that stage of his life. But at some point he stopped being a part of that stage and started being a part of his Twilight Years. For 
Paradox 2 to work, it has to be true that Eric is, atemporally, a part of his Youth. But that is no more true than it is true that Michael is, atemporally, a part of his cub-scout football team. And that cannot be true because, if it were, Michael's team would have to exist right now since (happily) Michael does. And it doesn't. Once we accept that we ought to relativize the instantiation relation, we see that both Eric and Michael have at-a-time their properties of being-a-part-of- $x$.

Grant that Eric is a part of his life. (We are not sure whether to say he is atemporally a part of his life. He is certainly not a temporary part of it in the sense of there being a time at which he exists but his life doesn't. But we can leave that issue aside.) It does not follow that he is, atemporally, a part of a part of his life, any more than it follows from the fact that Helen's brain is a part of her that her brain is also a part of her left foot. Eric is not atemporally a part of any part of his life. He is temporarily a part of his Youth and temporarily a part of his Twilight Years. Hence Eric's Youth does not exceed its required boundary - it stops as soon as Eric stops being a part of it. Hence there is no paradox. ${ }^{3}$

Centre for Philosophy, University of Manchester Manchester, M13 9PL, UK helen.beebee@man.ac.uk,michael.d.rush@man.ac.uk

\section{Bibliography}

Barker, S. and P. Dowe. 2003. Paradoxes of multi-location. Analysis 63/2: 106-14.

Haslanger, S. 1989. Endurance and temporary intrinsics. Analysis 49: 119-25.

Johnston, M. 1987. Is there a problem about persistence?. Aristotelian Society Supplementary Volume 61: 107-35.

Stout, R. 2003 (forthcoming). The Life of a Process. In Pragmatic Process Philosophy, ed. G. Debrock. Amsterdam: Rodopi.

\footnotetext{
${ }^{3}$ No cats were harmed in the writing of this reply.
} 